\title{
Introduction: Knowledge, Belief, and the Impulse to Natural Theology
}

\section{Fernando Vidal}

Max Planck Institute for the History of Science, Berlin

Bernhard Kleeberg

Justus-Liebig-Universität Giessen

The title of this issue of Science in Context - "Believing Nature, Knowing God" is intended to suggest the moral, emotional, and cognitive conditions in which the historical alliance of "nature" and "God" operated, and to make a more general point about knowing and believing. The production of scientific knowledge includes mechanisms for bringing about acceptance that such knowledge is true, and thus for generating a psychological state of belief. To claim to have knowledge of nature involves an attitude of belief in certain epistemic values, in the procedures associated with them, and in the results to which they lead. " Nature," both as a totality to be known, and as the sum of the results of research directed towards it, turns out to be an object of belief.

Reciprocally, even when the operations of nature are ultimately attributed to the action or will of a transcendent power, the production of justified statements about the existence, properties, and intentions of such power entails evidentiary and argumentative practices of the sort associated with the production of knowledge. Hence, whether we accept certain rational propositions and ways of reasoning because we adhere to the epistemic values of modern science or because we trust divine wisdom and benevolence, what is crucial for the validity of an argument is not that it rests on "knowledge" or "belief," but the authority we ascribe to the relevant practices of substantiating claims, be they in the laboratory or the church.

Within the history of science, natural theology is the most generally recognized expression of such intertwining of knowledge and belief. From the seventeenth to nineteenth centuries, "natural theology," or "physico-theology," as it has also been called since the mid-seventeenth century (Lorenz 1989), designated the knowledge of God drawn from the "book of nature," in contrast to knowledge of God contained as revelation in the "book of scripture." This division of theology into natural and revealed is rooted in a scholastic distinction between reason and faith, the one concerned with

\footnotetext{
${ }^{1}$ Philosophers speak of belief as a "propositional attitude," i.e., a mental state of having an attitude or opinion about a proposition or about the circumstances in which the proposition is true.
} 
propositions derived from nature by the use of Aristotelian logic, the other with truths revealed by God and taught through the authority of the Church. In its best-known form, natural theology came to be identified with "a demonstration of the being and attributes of God, from his works of creation" (Derham 1732). In that sense, as explained in the eighteenth-century Chambers' Cyclopaedia, natural theology is "the knowledge we have of God from his works, by the light of nature, and reason." From such a perspective, the harmony and order of nature are considered as evidence of God's wise design and benevolent purpose (Chambers 1741).

This way of knowing God points to the underlying anthropomorphic analogy between the divine creator of nature and a human artisan. The argument from design rests on the teleological proof of the existence of God, which can in turn be traced to older views that stress the immanent (Aristotle) or bestowed poietic structure (Plato) of nature. While Aristotle transferred the idea of human poiesis to a natura naturans, origin and end in itself, the construction plan of Plato's natura naturata lay outside nature, in the mind of a master-workman. The purposefulness manifest in the micro- and macrocosm, the finality and coherence of natural processes, nature's beauty and optimal organization with respect to man - all revealed wisdom, omnipotence, providence, and benevolent vigilance as attributes of a "highest architect" (Groh and Groh 1991).

The alliance of "nature" and "God" was such that, in his 1686 Free Enquiry into the Vulgarly Received Notion of Nature, the English natural philosopher Robert Boyle (16271691), a founding member of the Royal Society, argued that the notion of "nature" was as prejudicial to science as it was to religion (Boyle [1686] 1996). Accounting for phenomena by an appeal to nature precluded, in his view, the search and formulation of precise "physical reasons"; furthermore, reifying nature detracted from the honor due to the creator and defrauded "the true God." Of the eight meanings of "nature" Boyle distinguished, it was "nature" as the creating God (natura naturans) and as the created universe and its manifold phenomena (natura naturata) that corresponded, most often simultaneously or by slipping from one to the other, to the sense it had in natural theology. In that context, it was generally knowledge of created nature that confirmed, sustained, and gave precision to belief in God. When Adam Lord Gifford established the Gifford lectures in 1885, he defined their goal as being to "promote and diffuse the study of Natural Theology in the widest sense of the term - in other words, the knowledge of God" (Vande Kemp 2002, 2).

Nowadays, partisans of "intelligent design" (ID) maintain that an intelligent cause is a better explanation for the origins and function of the universe, and especially of living beings, than processes such as natural selection. By not specifying the identity or nature of the designer, they seem to offer an alternative to scientific materialism, and hope to fend off the accusation that they defend a religious doctrine. Nevertheless, as noted by a theologian who testified in a Pennsylvania court case brought by parents against a public school district requirement that ID be taught alongside evolution, ID "is not a new scientific argument, but is rather an old religious argument for the existence of God," traceable to the medieval and later induction from the design to 
the existence of a designer. ${ }^{2}$ In spite of its strategic roundabouts, ID is an obvious avatar of natural theology.

The recurrence of the teleological argument and the assumption that the world displays empirical "signs of intelligence" (title of a 2001 book by leading ID proponent William A. Dembski) may mask a more diverse narrative about ways of considering the relationship of nature and God. Indeed, in the history of Western Christianity, many thinkers who did not deal directly with design arguments were engaged in intellectual pursuits convinced that in believing Nature and in trusting their reasoning therefrom, they could know God and his plans. In the broader sense of what we shall call an "impulse to natural theology," moving from nature to God was also at work outside explicitly physicotheological texts and settings. The articles in this issue examine some instances of such an impulse, focusing less on particular scientific contents or disciplines than on historicizing the very notions of knowledge and belief, science and religion, as well as on examining various ways in which they functioned together as a crucial element for contexts of science.

\section{Knowledge and Belief}

The way the terms "knowledge" and "belief" are usually employed implies a dichotomy. We tend to say that we "believe" in X when we lack the kind of evidence that would allow us to affirm that we "know" X. If I think that the existence of God cannot be demonstrated, or I don't care about its proofs, then I can only believe in God, whether this conviction rests on the authority of a book, an institution, or my own conscience. In contrast, if the existence of God can somehow be demonstrated by empirical facts and rational arguments, then I may be able to know that God exists. It would seem that knowledge requires belief, but that belief, in contrast, does not necessitate knowledge. Belief, at least according to common usage of the term since the late seventeenth century, appears to stand on the side of subjectivity, opinion, and faith; knowledge, on the side of objectivity, proof, and science. The former is private or shared within limited groups, the latter is public and universal. In contemporary polemics, concerning for example the state of the environment or the use of genetically modified organisms in agriculture and foodstuff, belief tends to function as a term of abuse, as when ecologists are accused of basing their claims about climate change on apocalyptic beliefs rather than on scientific facts. Assuming that science provides the gold standard of certainty, all sides appeal to scientific knowledge to defend their position. Such controversies may well illustrate the power of ideological blinders, but they also suggest the practical problems of elevating science to the rank of moral and cognitive authority.

\footnotetext{
2 Tammy Kitzmiller, et al. v. Dover Area School District, et al. Case 4:04-cv-02688-JEJ, "Memorandum Opinion," Document 342, filed 20 December 2005, p. 24. Available at www.pamd.uscourts.gov/kitzmiller/ docket.htm.
} 
In the heat of the debate, the values of science, such as objectivity, disinterested quest for empirical evidence, rational and well-grounded theorizing, do not suffice to sustain knowledge, command belief, or unambiguously discriminate these two states.

Knowledge and belief, in fact, are much more intimately linked than is implied by our spontaneous dichotomies and their apologetic uses. To undertake research, we need belief, at least in the form of hypothesis or conjecture. At the other end, we cannot say that we know something unless we believe in it. We cannot know that the earth is round, and yet not believe that the earth is round. But we can believe that the earth is flat, or that a person loves us, without knowing that that is the case. On the other hand, there is more to knowledge than believing a truth. I may believe, without evidence, that a medical treatment works for me; but if, without my knowing it, a laboratory has proven that the treatment works in cases like mine, my belief is coincidentally true even though I don't know it. Knowledge therefore requires belief, but there is more to knowledge than believing that something is true.

Knowledge has often been defined as "justified true belief." Yet in some circumstances, known as "Gettier's problem" after the American philosopher Edmund Gettier, a true belief might be justified, even though the believer does not know the belief is true (Gettier 1963). Philosophers have therefore added a situational dimension to the definition of knowledge, which remains justified true belief, but acquired by a method that is reliable in the relevant context. In practice, however, even contextually appropriate methods do not guarantee legitimate knowledge.

Psychologists have studied what happens when people face a contradiction between different beliefs, or between a belief and something they come to know. In the 1950s, the social psychologist Leon Festinger (1919-1989) and his colleagues investigated the case of a small cult in the American state of Utah. The cult was led by a housewife known as Marian Keech. She prophesied that on December 21, 1954, a flood would destroy much of the earth, but that cult members would be saved by guardians from outer space. When the prophecy failed, the cult, instead of disappearing, became stronger: faced with "disconfirmation," its followers sought to reduce the resulting tension by trying to win more members for the group. In When Prophecy Fails, Festinger, Riecken, and Schachter ([1956] 1983) gave the psychological state produced by a contradiction between belief and knowledge the name, "cognitive dissonance." As later studies on the psychology of judgment and choice in situations of uncertainty have demonstrated, humans often reach optimal decisions by following simple heuristics and ignoring information (e.g., Goldstein and Gigerenzer 2002). The psychological states of awareness or ignorance may be irrelevant for the epistemological status of knowledge claims, but not for cognitive practices.

The complexity of these barely sketched and highly selective philosophical and psychological conundrums suggests that the problems raised by the relations of knowledge and belief cannot be solved normatively or abstractly. Certainly, knowledge and belief are concepts and mental states; but, as the articles in this issue try to illustrate, they are, preeminently, practices. To begin with, though, the meaning of the terms 
has changed over time, and their relationship has been conceived in different ways. The ancient Greek term episteme (Lat. scientia) signified a unique form of knowing that marked the highest point on a scale of certainty between mere opinion and theoretical knowledge. Resting upon a highly developed skill (techne) of justification and explanation, knowledge for Plato aimed at the eternal and ideal objects of the intelligible world, the mundus intelligibilis. In contrast, the permanently changing mundus sensibilis related to opinion or doxa. Doxa, in turn divided into conviction (pistis) and conjecture (eikasia), could only claim a low degree of certainty. It thus was the kind of pre-philosophical knowledge of the inhabitants of the Cave, who only perceived shadows of the "real" world of Platonic ideas (The Republic VII).

Still, some of the things perceived could unsettle pre-philosophical certainties and stimulate the quest for philosophical knowledge. To gain this kind of knowledge, theoria, one had to transcend the world of observable events, and engage in the theoretical contemplation of ideas, essences, or being. The goal of such "theoretical experience" was knowledge of nature as a whole, rather than of individual and particular phenomena. As a "twofold perception," it transcended the sensorial world by a "leap from the visible to the invisible" (R. Groh 1998). According to the notion of theoria tou kosmou, ${ }^{3}$ or the intuitive intellectual vision of the universe, there was a unity of the divine, the natural and the rational, and no gap between the true and the beautiful, between the rational and the aesthetic perception of nature. Beautiful nature represented true nature; its harmony, purposefulness, and order guided the eye of the beholder towards something that could not be directly observed. Such "meta-physical" knowledge was opposed to belief in the sense of opinions, convictions, and conjectures, but not to belief in the sense of religious certainty. Since the cosmos and its order were divine, theology and natural philosophy necessarily coincided. This was not confined to Platonism, as shown by Aristotle's ideas on the unmoved mover in Physics VII-VIII, Metaphysics XII, and De motu animalium 2-4, as well as on the circular movement of the primary body in De coelo (e.g., I.3).

Christian medieval theology would come to reject that kind of coincidence of theology and natural philosophy. Although truth in the realm of knowledge converged with truth in that of belief, revealed knowledge was deemed superior in certainty and clarity to knowledge gained through the exercise of human reason. The impulse to natural theology does surface in a statement of Augustine's Confessions that became an important source for the medieval tradition of the Book of Nature: "Then, truly, did I see clearly Thy invisible things, that are understood through those which are made. But, I was not able to keep my gaze fixed" (Confessions VII.17.23; cf. VII.20.26 and X.6.10). Although beautiful objects may point to their transcendent source, Augustine

\footnotetext{
${ }^{3}$ Anaxagoras according to Aristotle, Eudaemonian Ethics I, 5, 1216a; Plato, The Republic 523a,b, 475e, 476b and Theaetetus 155d; Aristotle, Metaphysics I, 2982 b, V, 1, 1026a, and X, 7, 1064b; Plotinus, Enneads 1.2,3 (see R. Groh 1998, 60).
} 
did not revel in their beauty, but demanded that they be used as a path to God, rather than enjoyed in themselves (De Doctrina Christiana I.4). Given the weakness of human reason that resulted from the fall, as well as human's desire to see (concupiscentia oculorum and cupiditas videndi), he considered objects of the natural world as "nothing but an ephemeral incentive to finding a God" (R. Groh 1998, 61).

Augustine's disregard for the visible world and his downplaying of natural knowledge indicate that the emphasis on reason as supreme arbiter, and even as grounds for the existence of God, was not inherently Christian. Rather, it was received from Greek sources translated from the Arabic, and commentated and elaborated upon by such Islamic philosophers as Avicenna and Averroes. The availability of those translations and commentaries sustained the emergence of a rationalist philosophy autonomous from divine revelation - a movement that Paris bishop Stephen Tempier tried to curb in 1277. In that year, Tempier condemned over two hundred philosophical and theological theses being disputed at the Faculty of Arts (Piché 1999; Thijssen 2003). In the preamble, he attacked what came to be known as the theory of the "double truth," namely the practice of evaluating a doctrine according to faith and, separately, from the point of view of philosophy. Such practice could lead to rationally demonstrated theories (e.g., the eternity of the world or the unity of the intellect, maintained by Averroes) that contradicted Christian doctrine. According to Tempier, some scholars claimed that some doctrines were true secundum philosophiam, sed non secundum fidem catholicam, quasi sint duae contrariae veritates - "as if there were two contrary truths." Nevertheless, as Hans Thijssen has pointed out,

there were no medieval authors who entertained the philosophically absurd theory that two contradictory propositions - one derived from philosophical investigation, the other from Christian revelation - can both be true at the same time. Rather, Tempier's reproach should be taken as an attempt to ridicule the hermeneutical practice of commentators to evaluate a doctrine (for instance Aristotle's) from a philosophical point of view .... and from faith. In reality, however, medieval scholars generally supposed that in cases of conflict between reason and faith, the truth was always on the side of the faith. (Thijssen 2003)

Though truth ultimately rested on faith, trust in reason was a driving force of scholastic philosophy. In the thirteenth century, Thomas Aquinas (1225-1274) distinguished between the "mysteries" and the "preambles" of Christian faith. Mysteries such as the Incarnation or the Trinity are revealed truths that reason alone could not have come to know. Preambles, in contrast, are truths, including the existence of God and the immortality of the soul, that do not depend exclusively on faith, but that reason can know by its own means. At the beginning of his Compendium Theologiae, composed during the last two years of his life, Aquinas wrote: "Regarding the existence of the divine essence, we must first believe that God exists. This is a truth clearly known 
by reason." He then argued that there must be an agent that sets the universe in motion. ${ }^{4}$ Denying the existence of such an agent, he explained, "would be like fancying that, when a chest or a bed is being built, the saw or the hatchet performs its functions without the carpenter. Accordingly, there must be a first mover that is above all the rest; and this being we call God" (Aquinas 2002, 9). ${ }^{5}$ Leaving aside for the moment what Aquinas wished to demonstrate, let us return to the opening phrases: "we must first believe that God exists" and "This is a truth clearly known by reason." We must believe; that is the basic condition of the faith. But our belief rests upon the dictates of reason.

"Authority" is here a key notion: belief is the assent we give to propositions because of authority. This authority can be human, and proceed from science, philosophy, logic, history, testimony, or any other human activity. Or it can be revealed in a book such as the Bible, in which case it is thought to derive from God, and is called "faith." Under certain conditions, reason, including what we now call "science," gives rise to the mental state we call "belief;" but the authority attributed to rational propositions depends in turn on beliefs about reason such that it is trusted as a source of true knowledge. ${ }^{6}$

\section{Natural Theology}

The ubiquity of the supposition - or prescription - of a strict dichotomy between science and religion is not consistent with the crucial role natural theology played in the emergence of modern science. At the top of its popularity among scholars in the seventeenth to nineteenth centuries, natural theology was the knowledge of God drawn "from his works of creation." Its aim was not to prove, but to justify theological propositions. The "demonstration" in the title of William Derham's Physico-Theology does not imply logical proof. Rather, in accordance with Psalm 19 - "The heavens declare the glory of God; the skies proclaim the work of his hands" - it announces the goal of exhibiting God in the order of nature, and thus of justifying belief in his existence.

\footnotetext{
${ }^{4}$ Aquinas' argument is consistent with Aristotle's doctrine of causes in Physics II.3, according to which one of the causes, known as "efficient," is the source of change or rest (as the father, says the philosopher, is the cause of his child).

${ }^{5}$ Cf. Summa theologica $\mathrm{I}^{\mathrm{a}}$, q. 2, a. 3 for the proofs of the existence of God, including the teleological quinta via ... ex gobernatione rerum.

${ }^{6}$ We employ "authority" in the general sense of that which commands opinion or behavior and to highlight the cognitive interdependence of knowledge and belief. The historically significant connotation of the authority of revelation as a coercive power that can be exerted against the free use of reason emerges especially in John Locke's premise that faith must be regulated by reason. Locke argued that a proposition (e.g., that one same body may be in two distant places at once) "cannot be admitted against the clear evidence of reason" even if it pretended "to the authority of a divine revelation" (Essay Concerning Human Understanding [1690] IV.18.5). For him, reason was the "proper judge" in all things, and nobody should be obliged to give up an opinion "under a pretence that it is matter of faith: which can have no authority against the plain and clear dictates of reason" (ibid., IV.18.6). Reason, he wrote, "is natural revelation," and "revelation is natural reason enlarged by a new set of discoveries communicated by God immediately" (ibid., IV.19). On the history of "authority," see Krieger 1973.
} 
The anthropomorphic analogy between the human and the divine artist, which had prominently been proposed in Plato's Timaeus and Cicero's De natura deorum (Book II) can also be found among early church fathers (D. Groh 2003): Clement of Alexandria spoke of the beautiful cosmos as the "temple of God," created for man; Origen of Alexandria believed in the union of ratio and fides in creation, in a cosmos animated by God's spirit and in the possibility to climb the "natural ladder" from the visible world towards the unseen; Basil of Caesarea proposed the idea that God is solely to be conceived via his deeds, e.g., the natural world as the divine work of art, created for the benefit, moral education, and growth of human knowledge; John Chrysostom inferred God's providence from creation and conceived nature as a divine mirror of God's benevolence.

The history of "natural theology" in the Latin Middle Ages is, however, complicated by issues of terminology. For many of the early church fathers, "theology" was a pejorative term, used to refer to pagan myths about the gods, while "philosophy" as love of wisdom could become, as with Augustine, synonymous with Christian truth (Bradley 1982, 582; Synan 1982, 616). Only with Peter Abelard (1079-1142) did medieval thinkers begin to employ the terms "theology" and "philosophy" in their modern sense, and even thereafter, many authors continued to use the terms sacra pagina and sacra doctrina to refer to what we call "theology" (Bradley 1982, 582-583; Principe 1982, 591; Synan 1982, 616-617). Furthermore, the phrase "natural theology" had its own set of connotations, traceable to Augustine's City of God (VI.5), in which theologia naturalis, encompassing conclusions that philosophers had reached about the gods, was clearly inferior to the truths contained in Christian doctrine. ${ }^{7}$ Other than in quotations from Augustine, the phrase appears hardly at all in medieval writings. ${ }^{8}$ Only in the fifteenth century does one begin to see medieval authors employing "natural theology" in a positive light to describe the use of human reason to investigate religious topics.

For many modern scholars, the question of knowledge and belief in the Latin Middle Ages has been much more focused around the issue Etienne Gilson (18841978) epitomized as "reason and revelation in the Middle Ages," than on the history of natural theology (Gilson 1938 and 1955; on his enduring influence, Marenbon 1998, 9). Through much of the twentieth century, historians of medieval thought traced a shifting relationship between reason and revelation. For them, the apex of this relationship was the synthesis of Thomas Aquinas, in whose great Summas reason (i.e., Aristotelian logic and philosophy) both establish certain preliminary truths of Christianity, such as God's existence, and elucidate more complicated aspects of the faith, such as the workings of the sacraments. In this historiographical account, the already-mentioned backlash against Averroism and philosophy in late thirteenth-century Paris marks the end of the

\footnotetext{
${ }^{7}$ Augustine refers to Varro's tripartitite division of theologia into mythicon (or fabulosa), physicon (or naturalis), and civile.

${ }^{8}$ Searches for "naturalis theologia" and "theologia naturalis" in the full-text database of the Patrologia Latina turn up only Augustine's City of God.
} 
delicate balance between reason and revelation, leading to the eventual separation of philosophy and theology, and plunging late medieval intellectuals into the pursuits of nominalism, fideism, and mysticism (Knowles 1962; Schall 2002). ${ }^{9}$

Among historians of science, the work of physicist and historian Pierre Duhem (1861-1916) opened the way for a more positive interpretation (consistent with Duhem's own Catholicism) of the impact of medieval theology. In the posthumously published volume of Le Système du monde devoted to the "reflux of Aristotelianism," he argued that modern science "was born" with the Paris decree of 7 March 1277 (Duhem 1954). In order to prevent restraints from being imposed on God's omnipotence, Tempier and his theologians council condemned Aristotelian physics. They thereby, according to Duhem, freed Christian scholars from the acceptance of Aristotelianism, and implicitly called for the creation of a new physics (see also Grant 1979). Yet, the trajectory of "rise and fall," or at least "crisis and resolution" (Dunphy 1982, 606), seems to remain an essential component of the way the dialogue between reason and faith in the medieval West is understood. ${ }^{10}$ Its persistence sheds light on how intricately, within the master narrative of the emergence of modern science, images of historical discontinuity are entangled with the idea of a clear-cut dichotomy of knowledge and belief (or of their being opposite extremes of a continuous scale).

A different picture emerges if we shift the focus towards works that were not specifically physicotheological, yet engaged with the interrelations of nature, reason, and God. Research into this wider context has questioned the old master narrative in a number of significant ways. In the first place, the Neoplatonism of scholars in twelfthcentury Chartres marks more of a high point in the impulse to natural theology than does the careful synthesis of a Thomas Aquinas. Scholars such as Thierry of Chartres, Clarenbaldus of Arras, and William of Conches produced works in which such central Christian tenets as the Creation, the Incarnation, and the Trinity were deduced by reason without recourse to revelation (see, most recently, Newman 2003, 51-111). Secondly, one finds the impulse to natural theology in works not traditionally understood to be theological, most importantly in the application of astrological theories to predict and understand religious changes, including the advent of the Antichrist and the timing of the Apocalypse. Third, far from representing a time of decline or retreat from human reason, the fourteenth and fifteenth centuries turn out

\footnotetext{
${ }^{9}$ In attenuated form, this narrative still governs the history of philosophy and theology traced in standard reference works, e.g., "The confident use of philosophy within theology of an Aquinas gave way to more cautious, even hostile, attitudes toward philosophy" (Dunphy 1982, 607); or Brown, "The harmony between nature and grace, reason and faith, study and prayerful contemplation, sometimes approached and frequently only hoped for in different ways by different theologians in the thirteenth century, became a more fading dream.... The medieval intellectual synthesis, to the extent that it was achieved, was breaking down into its component elements" (Brown 1982, 611).

${ }^{10}$ Haren, for example, acknowledges the work of recent scholars in rehabilitating late medieval thought, but insists that "the new regard for the later period does nothing to diminish the importance of the thirteenth century as a pivotal point in western cultural history" (Haren 1992, 210-211).
} 
to be a period of vital importance in the history of the complex relationship between knowing and believing.

In particular, a number of thinkers concerned about a seemingly imminent apocalypse engaged in astrological investigations of the End, at the same time advancing the argument that human reasoning from natural phenomena could, indeed, reach religious truths (DeVun 2004). For some scholars at least, by the fourteenth and fifteenth centuries, the Book of Nature stood as an independent and equal partner to the Book of Scripture, capable of leading a trained exegete to the same sorts of religious truths (on the history of the Book of Nature metaphor since antiquity, see van Berkel and Vanderjagt 2005, and Vanderjagt and van Berkel 2005). So, for example, appears nature in the Theologia naturalis, "or the Book of Creatures," written in the 1430s by Raimond Sebond, a Spanish theologian who taught in Toulouse. ${ }^{11}$ Finally, in the growing notion of a prisca theologia revealed to ancient figures such as Plato and Hermes Trismegistus, there is a sense that the boundaries between reason and revelation are blurring (Walker 1972; Schmidt-Biggemann 1988; Hanegraaff 2005). If philosophy or astrology were revealed to the ancients, then the sayings of philosophers or astrologers and the prophecies of inspired seers are equivalent. Reasoning from God's creation becomes of equal validity with his revealed word in Scripture. As the physician Walter Charleton (1619-1707) later proclaimed in the title of his 1652 physicotheological treatise, the "light of nature" could henceforth serve to dispel "the darkness of atheism."

In his will, Robert Boyle, a pious Anglican, endowed an annual series of eight sermons to prove the Christian religion "against Infidels," without entering into controversies among Christians themselves. Of the lectures preached between 1692 and 1793, the most famous and popular ones were natural theologies in the spirit of Boyle's own philosophy. ${ }^{12}$ By the eighteenth century, natural theology had become a well-established genre aimed at demonstrating, as proclaimed in the title of Derham's Boyle lectures, "the being and attributes of God, from his works of creation."

The idea that there is knowledge of God without revelation, and the ensuing distinction between natural and supernatural or revealed theology, had been thematized in scholastic thought. The novelty of seventeenth- and eighteenth-century natural

\footnotetext{
${ }^{11}$ Montaigne translated Sebond at his father's request; the translation was published in 1569. The Essays (II.12) include the influential "Apology for Raimond Sebond," in which Montaigne defends a skeptical view of knowledge and the idea that religion should be based on faith alone.

${ }^{12}$ In The Christian Virtuoso, for example, Boyle $(1690,17-18)$ noted that, contrary to the "experimental philosophy," the scholastic terminology of qualities and substantial forms does not lead "to deeper searches into the Structure of Things, nor the manner of being Produc'd, and of Operating upon one another. And consequently, are very inefficient to disclose the exquisite Wisdom, which the Omniscient Maker has express'd in the peculiar Fabricks of Bodies, and the skillfully regulated Motions of them, or of their constituent Parts: From the discernment of which things, nevertheless, it is, that there is, by way of result, produc'd in the mind of an Intelligent Contemplator, a strong Conviction of the Being of a Divine Opificer, and a just acknowledgment of his admirable Wisdom” (on the early Boyle lectures, see Dahm 1970).
} 
theology was its reliance on natural philosophy, as well as its focus on the cosmological and teleological proofs (of God as first cause, and of the universe as purposeful), at the expense of the ontological proof (derived a priori from the idea of God). Its assumptions were that everything has been designed for a purpose, and that the harmony and adaptiveness observed in the whole of Creation, as well as in each of its parts, manifest the goodness, wisdom, and existence of God. In physicotheology, wonder before the "spectacle of nature" (as reads the title of Abbé Pluche's 1732-1742 bestseller) was generated by science rather than by enthusiastic rhetoric alone, and involved collection, description, classification, experimentation, and exposition.

Following the Stoic tradition and Cicero's already mentioned De natura deorum, natural theologians elaborated analogies for the providential ends they perceived in the universe (Foster 1994). We have quoted Aquinas on the bed and the carpenter. Later on, the watchmaker became popular. For example, in his influential 1802 Natural Theology: or, Evidences of the Existence and Attributes of the Deity, Collected from the Appearances of Nature (chap. 5), the English divine William Paley (1743-1805) claimed that studying the mechanism of a watch led to the "inevitable" conclusion that the machine has a maker. He believed such reasoning applied to the eye, animals, plants, and, "indeed, all the organized parts of the works of nature." For Voltaire's Pangloss in Candide (1759), noses were shaped to support eye-glasses, and they did; stones were formed to be cut and serve to build castles, and so were they used. The caricature might be extreme, but the argument from design did express an anthropocentric and optimistic teleology. Human anatomy was an archetypal example. For the naturalist John Ray (1627-ca. 1705), the human body is "the effect of Wisdom, because there is nothing in it deficient, nothing superfluous, nothing but hath its End and Use" (Ray [1691] 1974, 155; Zeitz 1994). As the eighteenth-century German philosopher Christian Wolff (1679-1754) emphasized in a treatise whose title echoed Galen's “on the usefulness of the parts of the body," God's intentions are manifest in the functioning of all and every part of the body (Wolff [1725] 1980, 3-4, and Part I, chap. 1). The same held true for views of the macrocosm, where the idea of divine providence vested nature with value. For example, the problem of theodicy - how to justify the existence of evil in a universe created by a benevolent God - was given an answer in the idea that evil is only apparent, and actually contributes to the perfection of the divine plan (Marquard 1978; Groh and Groh 1991). In this and many other ways, nature functioned as supreme source of moral authority (Daston and Vidal 2004).

Historians now tend to consider that natural theology helped, rather than hindered science (Brooke 1989 and 1991; Krolzik 1980; on Darwin, see Ospovat 1981). They have studied the spread and impact of physico-theology as it was applied to an increasingly large range of objects and phenomena, from locusts and bees, or fire and stones, to plants, animals, humans, and beyond. Such objects belonged in the realm of the natural and the ordinary. The movements of the planets or those of the silkworm, the structure of plants or that of the beehive obeyed universal laws (Gillispie 
1951; Krolzik 1996; Philipp 1957 and 1967; Roger [1963] 1993, 224-249; Stebbins 1980 on Germany).

Nothing in those laws, except their origin and divinely ordained continuation, proceeded from outside nature. Natural theology sometimes considered preternatural events, i.e., occurrences that, though extraordinary, followed the usual laws of nature (Daston 1998 and 2000). Derham, for example, accepted as fact the Methuselah's longevity, but judged "fabulous" the Wandering Jew, or the man Roger Bacon claimed "that lived 900 Years by the help of a certain Medicine" (Derham 1732, 172-174). Derham's focus on naturalistic explanation went alongside trust in the scriptural word and skepticism about legendary phenomena that seemed to violate natural laws. In short, the physicotheological sensibility that emerged in seventeenth-century England fit into the metaphysical, ontological, and epistemological framework of what members of the Royal Society called new philosophy, and shared its emphasis on the invariability, universality, and simplicity of the laws of nature. This form of natural theology remained particularly strong in England and Germany throughout the eighteenth century. In the Netherlands, physico-theology provided the orthodox with a powerful alternative to the rationalizing implications of Cartesianism or Spinozism. Here, the descriptions of cosmology or of natural history generated a catechism of nature that could oppose more radical religious or political views (Israel 2001, 436-476; van der Wall 2004; Vermij 1991).

In Germany, natural theology was a popular and respectable genre at least until Immanuel Kant's devastating analysis of the 1780s. In the Critique of Pure Reason, Kant (1724-1804) explained that the argument from design concerns only the form, not the substance of the universe; it can "establish a highest architect of the world, who would always be limited by the suitability of the material on which he works, but not a creator of the world" (Kant [1781] 1998, A626-627). In the later Critique of Judgment (1790, $\S 85)$, he added that physico-theology is merely a "physical teleology" incapable of revealing anything about an ultimate purpose of creation. Yet Kant encouraged it as a means of elevating the mind "from the conditioned to the condition, up to the supreme and unconditioned author," and wrote that it would be "not only discomfiting but also quite pointless to try to remove anything from the reputation" of the physicotheological proof, as it "is the oldest, clearest and the most appropriate to common human reason" (Kant [1781] 1998, A623-624).

While most later German authors subscribed to Kant's argument against physicotheology for logical reasons, romantic natural philosophy embraced at least the aesthetic dimension of natural theology. Such thinkers as Johann Gottlieb Fichte, Friedrich Wilhelm Joseph Schelling, and Georg Wilhelm Friedrich Hegel followed Friedrich Schlegel's and Johann Wolfgang Goethe's justification of natural theology as appealing to the senses, as a way to correctly describe the joys of reveling in the beauty of nature (Schlegel [1799] 1963, $\mathrm{n}^{\circ}$ 1307, 303; Goethe [1833] 1953, 365f.). Though it did not rely exclusively on theistic views, but also on teleological and pantheistic concepts ("mother nature"), this aesthetic aspect formed the basis for most nineteenth-century 
German concepts of nature, including some commonly described as materialist (e.g., Vogt 1851, 28ff.). The aesthetics of nature had always been inseparable from such feelings of the beholder as fear, awe, and marvel (Daston and Park 1998; Groh and Groh 1991). These feelings were not only directed towards God, but also sustained by the anthropocentric sense, crucial for the impulse to natural theology, of nature's having been created in order to serve and be enjoyed by humankind. Such an optimistic outlook underlay the poetic and edifying side of most physicotheological literature. Against this background, it was possible to revel in nature, to feel joy while beholding the galaxies, the Alps, a human body, or a microscopic animal. In some cases, this kind of reveling was sufficient in itself - a "profane feast of the senses" (Seel 1991). But for those who followed the impulse to natural theology, to enjoy the beauty of nature was a contemplative experience in which the perception of a beautiful, harmonious and purposeful order led to a feeling of cosmic union, of being lifted up from nature to something higher - God, ultimate meaning, das Naturganze. This kind of aesthetic experience was common to early nineteenth-century naturalists, even if they did not adhere to romantic Naturphilosophie.

The blend of scientific aspiration, religious feeling, and aesthetic and metaphysical transport is given emblematic form in the "photogenic drawing" of "Christ's head on an oak leaf” (ca. 1839-40), by Johann Carl Enslen (1759-1849) (see this issue's cover). ${ }^{13}$ Enslen's message was obvious in its context, and converged with the meaning that pioneer of photography William Henry Fox Talbot (1800-1877) gave to the "photogenic" technique he had invented. In 1839, musing over the implications of his invention, Talbot scribbled, next to "Nature magnified by Herself, or, Nature's Marvels," a verse from Alexander Pope's Essay on Man (1734, line 332) that perfectly summarizes the natural theological enterprise: "And look thro' Nature up to Nature's God" (Nickel 1998, 21).

The individual experience of reveling in nature became one of the most important points of departure not only for nineteenth-century German Protestantism, but also for both romantic naturalists and experimental empiricists. The subjective moment of abandonment to nature's beauty was understood to bring about a kind of unmediated access to the truth of nature as a whole - a truth felt that could (and was necessary to) frame the scientific or philosophical analysis of phenomena. In this sense, scientific reasoning and aesthetic contemplation formed two sides of an epistemological coin. The unity of reasoning and feeling, the complementarity of aesthetics and science, was the leading principle of all those scientists who followed the legacy of Alexander von Humboldt's Cosmos. A Sketch of a Physical Description of the Universe (1845-62) - and this included "Darwinists" like Ernst Haeckel (Kleeberg 2005).

While most German authors alluded to the immanent beauty, harmony, and order of a natura naturans, natural theology in the "classical" sense remained strongest in the

\footnotetext{
${ }^{13}$ We thank Martin Barnes and Kelley Wilder for drawing our attention to Enslen's picture.
} 
British context, where it played an integral role in the development of nineteenthcentury science. The century opened with the publication of Paley's Natural Theology, at the heart of which lay the argument from design. Every time Paley contemplated a natural phenomenon that seemed well suited to its purpose - he was particularly partial to the popular example of the eye - he detected natural evidences of the essential unity and goodness of God. Exceptionally clear and well argued, his work quickly became "one of the most popular works of philosophical theology in the English language" (Brooke 1991b, 193).

Early in the 1830s Paley's book was joined by an eight-book series, commissioned in the will of Francis Henry Egerton, the eighth earl of Bridgewater, to expound "On the Power, Wisdom and Goodness of God as manifested in the Creation." Like Paley's Natural Theology, the so-called "Bridgewater Treatises" were a great publishing success. They were written by thinkers at the forefront of their fields, and the middle-class English reading public eagerly learned science from their attempts to show God at work in the natural world. Aside from their underlying agreement on the legitimacy of natural theological argumentation, there was little unity among the Bridgewater treatises. This agreement, however, sufficed to provide a "common context" for scientific, economic, political, and theological discussion throughout the 1830s and 1840s (Young 1985). ${ }^{14}$

Even as the Bridgewater authors were following the "power, wisdom and goodness of God" through the natural world, external forces were rapidly changing England's religious landscape. The repeal of the Test and Corporation Acts in 1828, and the Catholic Emancipation Bill of 1829 signaled the country's move into a more religiously diverse and inclusive society. The founding of the British Association for the Advancement of Science in 1831 has long been seen as representative of science's move away from places which, like the Royal Society, had deep roots in the Anglican establishment.

As physicotheological discussion moved out of its traditional church environment in the 1830s, many of England's most sophisticated scientific thinkers found themselves trying to justify and defend religious arguments outside of a religious context. Their specific problem was the epistemological weakness of the analogical reasoning at the heart of natural theology. Decades before Paley's Natural Theology, in the posthumously published Dialogues Concerning Natural Religion, David Hume (17111776) had emphatically made this point. Yet his attempts to hold the argument from design to a philosophical, as opposed to a religious, standard, did not gain much traction until the 1830s. Paley tried (and failed) to reform natural theology by insisting on the identity of the mechanical constitution of machines and living organisms (Gillespie 1990); others who defended it against Hume claimed the human mind was in harmony

\footnotetext{
${ }^{14}$ For an entrance into the vast literature on early Victorian science and natural theology, see Brooke, Osler, and van der Meer 2001. On the authorship of the Bridgewater treatises, see Gillispie 1951, 209-216; Brock 1967; Robson 1990; for their audience, see Topham 1992 and 1998.
} 
with the mind of God, and that humans could be trusted to reason to right conclusions (Yeo 1979).

The case of William Whewell (1794-1866) may be used to illustrate this dynamic (Yeo 1979 and 1993; Brooke 1991a). Whewell made his first statements about the nature of science in a series of sermons delivered at St. Mary's church in the winter of 1827. Speaking from the pulpit, he was clear about the evocative character of natural theology. Science, he explained, would not lead men to God, "for that the spirit of God only can do." However, once securely within the Christian fold, the pursuit of science will "feed and elevate their devotion" (Whewell 1827a). Whewell spent his second sermon explaining the way inductive science served this devotional function. Induction became a process "of deep thought and of slow discovery" that pulled the investigator away from the chaotic particularities of the material world to contemplate ever wider and clearer scientific laws; "after such a discovery, we have learnt no new fact - these [the laws] are as they before were." What was new was an overwhelming realization that the facts are related according to "some principle of union and unity, some community of operation." The essential part of such insight was the way it pointed to "an Intelligent Ruler" who, albeit hidden from us, is "employed in deducing, from the laws, the facts." Whewell thus concluded, "it is then, no imaginary relations, no unreal and visionary principles that we pursue through the complications of the material world. What we seek to know are the Eternal and Universal ordinances by which it seems good to Him, the great author of All, to lead on the events of this, his creation" (Whewell 1827b).

Even as Whewell was sharing his devotional view of inductive science with the parishioners of St. Mary's, the world in which church was the appropriate place for such a discussion was about to be dismantled. Over the course of the next several years Whewell developed his views of inductive science in a series of publications: in 1833, a Bridgewater Treatise entitled Astronomy and General Physics Considered with Reference to Natural Theology; in 1837, a three-volume History of the Inductive Sciences; in 1840, a two-volume Philosophy of the Inductive Sciences. This record reflects the larger cultural movement that, during the 1830s in England, took serious discussion of science away from a local religious context, through the natural theology of a published Bridgewater treatise, into the religiously neutral world of philosophy (Fisch 1991). In the process, Whewell confronted a world that was institutionally dividing secular knowing from religious believing. In his Philosophy of the Inductive Sciences he brought this division into his philosophical thinking when he drew a sharp distinction between those things that were known with absolute certainty - "necessary truths" - and those which were merely known contingently - "experiential truth." Even as he proposed it, however, Whewell was uncomfortable with this separation. In a later paper he emphasized that this distinction was imposed by an essentially artificial disciplinary boundary; it was, to use his words with our emphasis, "the fundamental antithesis of philosophy" (Whewell 1844).

Many among Whewell's contemporaries were critical of the details of his attempt to negotiate the shift from a religious to a philosophically-based natural theology. Few, however, questioned the conviction that "the mind of man is represented as in harmony 
with universal nature; that we are capable of attaining real knowledge; and the design and intelligence that we trace through creation is no visionary conception, but a truth as certain as the existence of that creation itself" (Herschel 1841, 182; see Richards 1992 for more on the shift in the status of natural theology). This statement, by the astronomer John Herschel (1792-1871), captures nineteenth-century English natural theology at its most powerful - and most vulnerable. The Oxford movement that flourished in the 1830s questioned not only the alliance of church and state, but also that of science and religion. For example, John Henry Newman (1801-1890), one of its leaders, who converted in 1845 to Catholicism, agreed with the Protestant Macaulay that natural theology was not "a progressive science," since its questions and answers had not changed in over two-thousand years, and dismissed it as intellectually inconclusive and useless for faith. ${ }^{15}$ Later on, some churchmen did greet On the Origin of Species enthusiastically, and in 1860, Harvard botanist Asa Gray published his "Natural Selection Not Inconsistent With Natural Theology" (reprinted in Darwiniana, 1876). Nevertheless, the alternative Charles Darwin offered to the design Paley and other natural theologians had observed and celebrated would indeed contribute to destroy the certainty Herschel had proclaimed, and to dissolve the holy alliance of science and religion.

\section{$* * *$}

Natural theological thinking in the variegated forms sketched above rested on shared assumptions about nature, God, and human reason. Far beyond a refutation of atheism through the argument from design, these assumptions sustained a broader and more complex natural theological impulse. The articles in the present volume examine several contexts in which this impulse was at work. Shifting our attention away from the loci classici of the proofs of God's existence, we have made room for astrological analyses of religion in medieval Italy, Thomas Aquinas' concept of faith as practice and as organizing principle of knowledge and belief, the varieties and functions of natural theology in seventeenth-century England, miracle inquests in the eighteenth-century Roman Catholic Church, the dynamics of reason and faith in two generations of English nineteenth-century intellectuals, and the development of a "scientific religion" in German evolutionary monism around 1900.

In each case, a religious framework informs the thinking of persons moved by the impulse to natural theology. Yet, each subject operates within specific social and historical circumstances to which natural theological investigations somehow respond. In all instances, procedures to gain knowledge about nature are not merely aimed at

\footnotetext{
${ }^{15}$ See especially Sermon 5 (1856) in Sermons Preached on Various Occasions (1874), as well as The Idea of a University (1852/1858) II.7 (Christianity and Physical Science), where Newman quoted Thomas Babington Macaulay's review of the English translation of Leopold von Ranke's The Ecclesiastical and Political History of the Popes of Rome, during the Sixteenth and Seventeenth Centuries (1840, republished in Critical and Historical Essays, 1843).
} 
supporting some belief. Rather, they entail intellectual and social mechanisms aimed equally at producing belief in the value and legitimacy of the methods used and the evidence generated. While authors engaged in natural theological activities affirm or discover religious truths by their study of nature, they express, at the same time, their faith in an epistemology that trusts the perceptions of the senses and the faculty of reason. Ultimately, it is by "believing nature" that the individuals and communities studied here attain that intellectual state we have proposed to epitomize with the phrase "knowing God."

\section{Acknowledgments}

This volume on "Believing Nature, Knowing God" had its genesis in the Natural Theology section of the working group "Knowledge and Belief" organized by Lorraine Daston and Fernando Vidal, and sponsored by the Max Planck Institute for the History of Science. The authors of the following articles wish to acknowledge the intellectual stimulation provided by other members of the group, and to thank the Max Planck Institute for its generous support. While this Introduction is signed by two of us, it results from the collaboration of all the authors of this issue. For their comments on drafts of this Introduction, we thank especially Lorraine Daston and F. Jamil Ragep.

\section{References}

Aquinas, Thomas. 2002. Shorter Summa. Translated by Cyril Vollert. Manchester. NH: Sophia Press. (This translation was first published in 1947 as The Compendium of Theology.)

Augustine. 1953. Confessions. Translated by Vernon J. Bourke. Washington D.C.: Fathers of the Church, Inc.

Bowler, Peter J. 1992. The Non-Darwinian Revolution. Reinterpreting a Historical Myth, 2nd ed. Baltimore and London.

Boyle, Robert. [1686] 1996. A Free Enquiry into the Vulgarly Received Notion of Nature. Edited by Edward B. Davis and Michael Hunter. New York: Cambridge University Press.

Boyle, Robert. 1690. The Christian Virtuoso: Shewing, That by being addicted to Experimental Philosophy, a Man is rather Assisted, than Indisposed, to be a Good Christian. [London:] In the Savoy.

Bradley, Denis J. M. 1982. "Philosophy and Theology, Western European: To Mid Twelfth Century." In Strayer 1982, vol. 9.

Brock, W. H. 1967. "The Selection of the Authors of the Bridgewater Treatises." Notes and Records of the Royal Society of London 21:162-179.

Brooke, John Hedley. 1989. "Science and the Fortunes of Natural Theology: Some Historical Perspectives." Zygon 24:3-22.

Brooke, John Hedley. 1991a. "Indications of a Creator: Whewell as Apologist and Priest." In William Whewell: A Composite Portrait, edited by Menachem Fisch and Simon Schaffer, 149-174. Oxford: Clarendon Press.

Brooke, John Hedley. 1991b. Science and Religion. Some Historical Perspectives. Cambridge: Cambridge University Press. 
Brooke, John Hendley, Margaret Osler, and Jitse M. van der Meer, eds. 2001. Science in Theistic Contexts: Cognitive Dimensions (Osiris 16). Chicago: University of Chicago Press.

Brown, Stephen F. 1982. "Philosophy and Theology, Western European: Late Medieval.” In Strayer 1982, vol. 9.

Chambers, Ephraim. 1741. "Theology, natural." In Cyclopaedia: or, an Universal Dictionary of Arts and Sciences .... 4th ed. London: printed for D. Midwinter.

Dahm, John J. 1970. "Science and Apologetics in the Early Boyle Lectures." Church History 39:172-186.

Daston, Lorraine. 1998. "The Nature of Nature in Early Modern Europe." Configurations 6:149-172.

Daston, Lorraine. 2000. "Preternatural Philosophy." In Biographies of Scientific Objects, edited by L. Daston. Chicago: University of Chicago Press.

Daston, Lorraine, and Katharine Park. 1998. Wonders and the Order of Nature 1150-1750. New York: Zone Books.

Daston, Lorraine, and Fernando Vidal, eds. 2004. The Moral Authority of Nature. Chicago: University of Chicago Press.

Derham, William. 1732. Physico-Theology: Or, A Demonstration of the Being and Attributes of God, from his Works of Creation. London: printed for W. Innys. First published in 1713.

DeVun, Leah. 2004. "John of Rupescissa and the States of Nature: Science, Apocalypse, and Society in the Late Middle Ages." Ph.D. diss., Columbia University.

Duhem, Pierre. 1954. Le Système du monde. Histoire des doctrines cosmologiques de Platon à Copernic (19131959), vol. 6 (Le reflux de l'aristotélisme). Paris: Hermann.

Dunphy, William. 1982. "Philosophy and Theology, Western European: Thirteenth-Century Crisis." In Strayer 1982, vol. 9.

Enslen, Johann Carl. 1841. Versuch, die Natur des Lichtes aus seinen Erscheinungen zu erklären. Dresden and Leipzig: Arnold.

Festinger, Leon, Henry W. Rieken, and Stanley Schachter. [1956] 1983. When Prophecy Fails. A Social and Psychological Study of a Modern Group that Predicted the Destruction of the World. New York: Harper and Row.

Fisch, Menachem. 1991. William Whewell: Philosopher of Science. Oxford: Clarendon Press.

Foster, David. 1994. "'In Every Drop of Dew': Imagination and the Rhetoric of Assent in English Natural Religion.” Rhetorica 23:293-325.

Gettier, Edmund L. 1963. "Is Justified True Belief Knowledge?” Analysis 23:121-23.

Gillespie, Neal C. 1990. "Divine Design and the Industrial Revolution. William Paley's Abortive Reform of Natural Theology." Isis 81:214-229.

Gillispie, Charles Coulston. 1951. Genesis and Geology. A Study in the Relations of Scientific Thought, Natural Theology, and Social Opinion in Great Britain, 1790-1850. Cambridge, Mass.: Harvard University Press.

Gilson, Étienne. 1938. Reason and Revelation in the Middle Ages. New York: Charles Scribner's Sons.

Gilson, Étienne. 1955. History of Christian Philosophy in the Middle Ages. New York: Random House.

Goethe, Johann Wolfgang. [1833] 1953. "Maximen und Reflektionen." Goethe's Werke, vol. 12, edited by Erich Trunz. Hamburg: Wegner.

Goldstein, Daniel P. and Gerd Gigerenzer. 2002. "Models of Ecological Rationality: The Recognition Heuristic." Psychological Review 109:75-90.

Grant, Edward. 1979. "The Condemnation of 1277, God's Absolute Power, and Physical Thought in the Late Middle Ages." Viator 10:211-244.

Groh, Dieter. 2003. Schöpfung im Widerspruch. Deutungen der Natur und des Menschen von der Genesis bis zur Reformation. Frankfurt am Main: Suhrkamp.

Groh, Ruth. 1998. "Van Eyck's Rolin-Madonna as a Response to the Crisis of Medieval Universalism. An Approach from the Aesthetics of Nature." Compar(a)ison 2:57-77.

Groh, Ruth and Dieter Groh. 1991. Zur Kulturgeschichte der Natur, I: Weltbild und Naturaneignung. Frankfurt am Main: Suhrkamp. 
Hanegraaff, Wouter J. 2005. “Tradition.” In Dictionary of Gnosis and Western Esotericism, vol. 2, edited by W. Hanegraaff. Leiden: Brill.

Haren, Michael. 1992. Medieval Thought: The Western Intellectual Tradition from Antiquity to the Thirteenth Century. Toronto and Buffalo: University of Toronto Press.

Herschel, John. 1841. Review of Whewell's History of the Inductive Sciences (1837) and Philosophy of the Inductive Sciences (1840). Quarterly Review 68:177-238.

Israel, Jonathan I. 2001. Radical Enlightenment. New York: Oxford University Press.

Kant, Immanuel. [1781] 1998. Critique of Pure Reason. Translated and edited by Paul Guyer and Paul Wood. Cambridge: Cambridge University Press.

Kleeberg, Bernhard. 2005. Theophysis. Ernst Haeckels Philosophie des Naturganzen. Köln and Weimar: Böhlau.

Knowles, David. 1962. The Evolution of Medieval Thought. New York: Vintage Books.

Krieger, Leonard. 1973. "Authority." In Dictionary of the History of Ideas, vol. 1, edited by Philip P. Wiener. New York: Charles Scribner's Sons.

Krolzik, Udo. 1980. "Das physikotheologische Naturverständnis und sein Einfluß auf das naturwissenschaftliche Denken im 18. Jahrhundert.” Medizinhistorisches Journal 15:90-102.

Krolzik, Udo. 1996. "Physikotheologie." In Theologische Realenzyklopädie, vol. 26, edited by Gerhard Müller et al. Berlin and New York: Walter de Gruyter.

Lorenz, S. 1989. "Physikotheologie.” In Historisches Wörterbuch der Philosophie, vol. 7, edited by Joachim Ritter, Karlfried Gründer, and Gottfried Gabriel. Darmstadt: Wissenschaftliche Buchgesellschaft.

Marenbon, John, ed. 1998. Medieval Philosophy. Routledge History of Philosophy, vol. 3. London and New York: Routledge.

Marquard, Odo. 1978. "Glück im Unglück. Zur Theorie des indirekten Glücks zwischen Theodizee und Geschichtsphilosophie.” Allgemeine Zeitschrift für Philosophie 3:23-42.

Newman, Barbara. 2003. God and the Goddesses: Vision, Poetry, and Belief in the Middle Ages. Philadelphia: University of Pennsylvania Press.

Nickel, Douglas R. 1998. "Nature's Supernaturalism: William Henry Fox Talbot and Botanical Illustration." In Intersections. Lithography, Photography, and the Traditions of Printmaking, edited by Kathleen Stewart Howe, 15-23. Albuquerque: University of New Mexico Press.

Ospovat, Dov. 1981. The Development of Darwin's Theory: Natural History, Natural Theology, and Natural Selection, 1838-1859. New York: Cambridge University Press.

Paley, William. 1802. Natural Theology: Or, Evidences of the Existence and Attributes of the Deity, Collected from the Appearances of Nature. London: Printed for R. Faulder.

Philipp, Wolfgang. 1957. Das Werden der Auflkärung in theologiegeschichtlicher Sicht. Göttingen: Vandenhoeck \& Ruprecht.

Philipp, Wolfgang. 1967. "Physicotheology in the Age of Enlightenment: Appearance and History." Studies on Voltaire and the Eighteenth Century 57:1233-1267.

Piché, David (in collaboration with Claude Lafleur). 1999. La condamnation parisienne de 1277. Latin text, translation, introduction and commentary. Paris: Vrin.

Principe, Walter H. 1982. "Philosophy and Theology, Western European: Twelfth Century to Aquinas." In Strayer 1982, vol. 9.

Ray, John. [1691] 1974. The Wisdom of God Manifested in the Works of the Creation. Hildesheim: Georg Olms.

Richards, Joan L. 1992. "God, Truth and Mathematics in Nineteenth-Century England.” In The Invention of Modern Science, edited by Mary Jo Nye, Joan L. Richards, and Roger Steuer, 51-78. Dordrecht: Kluwer Academic.

Robson, Jon M. 1990. "The Fiat and the Finger of God: The Bridgewater Treatises." In Victorian Faith in Crisis: Essays on Continuity and Change in Nineteenth-Century Religious Belief, edited by Richard J. Helmstadter and Bernard Lightman, 71-125. London: Macmillan.

Roger, Jacques. [1963] 1993. Les Sciences de la vie dans la pensée française du XVIIIe siècle. Paris: Albin Michel. 
Schall, James V. S. J. 2002. "Possessed of Both a Revelation and a Reason.” In A Thomistic Tapestry: Essays in Memory of Etienne Gilson, edited by Peter Redpath, 177-191. Amsterdam: Rodopi.

Schlegel, Friedrich. [1799] 1963. "Philosophische Fragmente." In Kritische Friedrich Schlegel Ausgabe, edited by Ernst Behler. Paderborn: Schöningh. Vol. 18.

Schmidt-Biggemann, Wilhelm. 1998. Philosophia Perennis: Historische Umrisse abendländischer Spiritualität in Antike, Mittelalter und Früher Neuzeit. Frankfurt am Main: Suhrkamp.

Seel, Martin. 1991. Eine Ästhetik der Natur. Frankfurt am Main: Suhrkamp.

Stebbins, Sara. 1980. Maxima in minimis. Zum Empirie- und Autoritätsverständnis in der physikotheologischen Literatur der Frühaufklärung. Frankfurt am Main: Peter Lang.

Strayer, Joseph Reese, ed. 1982. Dictionary of the Middle Ages. New York: Scribner's.

Synan, Edward, A. 1982. "Philosophy and Theology, Western European: Terminology." In Strayer 1982, vol. 9.

Thijssen, Hans. 2003. “Condemnation of 1277.” In Stanford Encyclopedia of Philosophy. http://plato.stanford. edu/entries/condemnation/. Last accessed 30 March 2007.

Topham, Jonathan. 1992. "Science and Popular Education in the 1830s: The Role of the Bridgewater Treatises." British Journal for the History of Science 25:397-430.

Topham, Jonathan. 1998. "Beyond the Common Context: the Production and Reading of the Bridgewater Treatises." Isis 89:233-262.

van Berkel, Klaas, and Arie Johan Vanderjagt. 2005. The Book of Nature in Early Modern and Modern History. Leuven: Peeters.

Van der Wall, Ernestine G. E. 2004. "Newtonianism and Religion in the Netherlands." In Newton and Newtonianism, edited by Scott Mandelbrote. Studies in History and Philosophy of Science 35A(3):493514.

Vande Kemp, Hendrika. 2002. "The Gifford Lectures on Natural Theology: Historical Background to James's 'Varieties'." Streams of William James 4(3):2-8.

Vanderjagt, Arie Johan, and Klaas vanBerkel. 2005. The Book of Nature in Antiquity and the Middle Ages. Leuven: Peeters.

Vermij, Rienk H. 1991. Secularisering en natuurwetenschap in de zeventiende en achttiende eeuw. Amsterdam: Rodopi.

Vogt, Carl. 1851. Untersuchungen über Tierstaaten. Frankfurt am Main: Literarische Anstalt.

Walker, D. P. 1972. The Ancient Theology: Studies in Christian Platonism from the Fifteenth to the Eighteenth Century. Ithaca: Cornell University Press.

Whewell, William. 1827a. Sermon delivered in St. Mary's, 4 February. Trinity College Library. Whewell Papers. R.6.1713.

Whewell, William. 1827b. Sermon delivered in St. Mary's, 11 February. Trinity College Library. Whewell Papers. R. 6. 1714.

Whewell, William. 1844. "The Fundamental Antithesis of Philosophy." Transactions of the Cambridge Philosophical Society VII, part 2:170-181.

Wolff, Christian. [1725] 1980. Vernünffige Gedanken von dem Gebrauche der Theile in Menschen, Thieren und Pflantzen. Hildesheim: Georg Olms.

Yeo, Richard. 1979. "William Whewell, Natural Theology and the Philosophy of Science in Mid Nineteenth Century Britain." Annals of Science 36:493-516.

Yeo, Richard. 1993. Defining Science: William Whewell, Natural Knowledge and Public Debate in Early Victorian Britain. Cambridge: Cambridge University Press.

Young, Robert M. 1985. Darwin's Metaphor: Nature's Place in Victorian Culture. Cambridge: Cambridge University Press.

Zeitz, Lisa M. 1994. “Natural Theology, Rhetoric, and Revolution: John Ray's 'Wisdom of God,' 1691-1704.” Eighteenth-Century Life 18:120-133. 